\title{
REAL AND IMAGINARY PLACES OF (BE)LONGING IN THE WORK OF VLADA UROŠEVIĆ ${ }^{1}$
}

\author{
Lidija Kapuševska-Drakulevska \\ Ss Cyril and Methodius University, Skopje \\ 1.drakulevska@flf.ukim.edu.mk
}

Choosing childhood, city and dream as a threefold Ariadne's thread uncoiling through the paths of the labyrinth of his work, Urošević chronotopically hybridizes, through a harmonious combination, the real and the imaginary, a dream and reality, the near and the far, experience and memory, Order and Adventure, life and creation. If childhood is a paradise lost, a true emanation of the wondrous, and city, in a sense, the centre of the world, a cosmos preserving the palimpsestic traces of the past, while at the same time being also adjustable to personal yearnings, then dream denotes 'the end' of the familiar reality and 'the beginning' of some other, fantastic or surreal reality, subject to different laws and logic, but equally true and crucial to our existence.

Keywords: Vlada Urošević, childhood, city, dream

\footnotetext{
${ }^{1}$ This paper is conducted as part of Languages, literatures, cultures: educational policies for the advancement of modern society, a project funded by the Blaže Koneski Faculty of Philology, Skopje. Parts of this research paper have been presented at REELC 6th International Congress, Dublin City University and National University of Ireland, Galway, August 24-28th , 2015.
} 


\section{РЕАЛНИ И ИМАГИНАРНИ МЕСТА НА ПРИПАДНОСТ ВО ДЕЛОТО НА ВЛАДА УРОШЕВИК ${ }^{1}$}

Лидија Капушевска-Дракулевска

Универзитет „Св. Кирил и Методиј, Скопје

1.drakulevska@flf.ukim.edu.mk

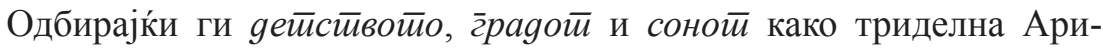
јаднина нишка која се провлекува низ лавиринтските патеки на неговото творештво, Урошевиќ хронотопски ги вкрстува во едно хармонично созвучје: реалното и имагинарното, јавето и сонот, блиското и далечното, искуството и сеќавањето, Редот и Авантурата, животот и креацијата. Ако gейсиивойо е загубениот рај, вистинска еманација на чудесното, а $\bar{z} p a g o \bar{u}$, во некоја смисла, средиште на светот, космос кој ги чува палимпсестните траги од минатото, но едновремено е и прилагодлив на личните копнежи,

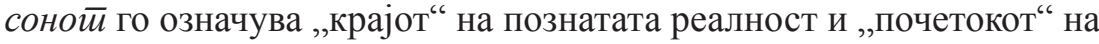
некоја друга, фантастична или надреална реалност, потчинета на поинакви закони и логика, но подеднакво вистинита и клучна за нашето суштествување.

Клучни зборови: Влада Урошевиќ, детство, град, сон

\footnotetext{
1 Статијата е изработена во рамките на макропроектот „Јазици, книжевности, култури: образовни политики во функција на современото општество“ на Филолошкиот факултет „Блаже Конески“ во Скопје. Делови од текстот се презентирани на REELC 6th International Congress одржан на Универзитетот во Даблин Сити и Националниот Универзитет на Ирска, во Галвеј, 24-28 август 2015.
} 


\section{Introduction}

Vlada Urošević (b. 1934) is one of the most eminent contemporary Macedonian authors - poet, prose writer, translator and essayist. From the aspect of poetics, his discourse relates to the legacy of the European avant-garde, with the experiences of which he evidently shows a profound affinity. As a poet he is a representative of the generation of poets of the period immediately following World War II. This was the generation which brought supreme inventiveness in the poetic language and expression and has definitely determined the physiognomy of the Macedonian poetry as "European".

During his six decades of permanent presence on the Macedonian literary stage so far, Urošević has given his contribution not only as a poet, but also as a writer of novels, short stories, translator of poetry, anthologist, travel writer, essayist, literary and art critic. And in each of these spheres he has been successful in offering a new, exciting, impressive and unpredictable adventure. On a contemplative level, the work of this author hides palimpsestic traces of ancient cultural (primarily mythical) layers (visible in his short stories and novels), as well as matrixes (auditory effects) from some magical formulaic wording (dominant in his poetry), all the way to certain symbols with archetypal meaning in the Jungian sense of the term (particularly present in his literary reviews and essays, but also in his poetry and prose writings). On the reflective level, the work of Urošević also corresponds with some other artistic spheres (painting) as well as with certain non-artistic, primarily scientific spheres (archaeology, astronomy, physics, psychoanalysis), but also with certain pseudoscientific spheres (esoteric teachings), while his constant preoccupation on the spiritual level is also the dialogue with other writings (ranging from Gilgamesh to Borges), and the "choice by affinity" of an entire pleiad of literary predecessors whose works have been processed in his translation laboratory (Gerard de Nerval, Charles Baudelaire, Arthur Rimbaud, Guillaume Apollinaire, Blaise Cendrars, Andre Breton, Henri Michaux, Alain Bosquet).

Choosing childhood, city and dream as a threefold Ariadne's thread uncoiling through the paths of the labyrinth of his work, Urošević chronotopically hybridizes, through a harmonious combination, the real and the imaginary, dream and reality, the near and the far, experience and memory, Order and Adventure, life and creation... If childhood is paradise lost, a true emanation of the wondrous, and city, in a sense, the centre of the world, a cosmos preserving the palimpsestic traces of the past, while at the same time being also adjustable to personal yearnings, then dream denotes 'the end' of the familiar reality and 'the beginning' of some other, fantastic or surreal reality, subject to different laws and logic, but equally true and crucial to our existence. 


\section{Before all and above all - childhood ${ }^{2}$}

For Urošević, childhood is the segment that connects the personal and the creative:

[In childhood] we approach the world as a huge secret, we enter into it as a treasure cave, not knowing what to touch first. Every single moment brings new experiences and everything we touch, everything we taste, everything we see, is in some way significant. Everything bathes in the sparkling light of revelation, and at the same time everything hides in its core certain tantalizing enigma the solution of which eludes us (Урошевиќ 2011:7).

Even the war, the deportation, the bombardments, all that "panicky nightmare" and "gory spectacle", "seen with the eyes of a child", held something "lustrous and fascinating" - Urošević infers.

It is not difficult to recognize in the above vision the far echo of Guillaume Apollinaire, one of Urošević's favourite literary predecessors, who also wrote verses about the marvels of war:

How beautiful those rockets are lighting up the night

They rise to their own summit and then lean down to look at us

They are women who dance with an awareness of eyes, arms and hearts...

(Guillaume Apollinaire, The Marvel of War)

Still, generally speaking, the vision of childhood in Urošević corresponds much more with the creative practice of an Arthur Rimbaud - to him, childhood per se is a totality and infinity, and poetically - the age of "clairvoyance" ("Our feeble reason hides the infinite from us!"- wrote Rimbaud); similarly, it also corresponds with the surrealistic fascination with the world seen through the "lens of children's eyes" as one of the states of spirit enabling entry into the spaces of the surreal, as well as with some of Charles Baudelaire's views as expressed in The Painter of Modern Life and Other Essays (1859): "The child sees everything in a state of newness; the child is always 'drunk" read in this essay.

Nothing resembles more what we call inspiration than the delight with which the child absorbs form and colour. But genius is nothing more nor less than childhood recovered at will...

(Baudelaire quoted in Ulich 2003: 189).

2 The title of one of Urošević's essays in his book Childhood, Summer, the City (Skopje, 2011, pp. 7-11). 
In his memories of the books he was attracted to in childhood ("Books of the Distant Summer Afternoons"), Urošević says:

I loved the books that could be leafed through countless times, and whose meaning could be completed with fantasy (...) In all the books I have read since I seem to have looked for that contact with the mysterious, uncommon and unknown that I had felt when turning the pages of those books of my childhood. Likewise, everything I've written is probably just an attempt to reconstruct their text which is - for me - forever shrouded in mystery. Futile attempt, of course (Урошевиќ 2011:49; 51).

And again allusions, this time to Picasso, who is said to have stated that his whole life he was "trying to learn how to draw like a child, and never succeeded."

The stage of childhood is, naturally, dominated by the children as personae actants. And while in poetry the subject is always impersonal, in prose writings the narrator frequently appears in the "I" form. So, in texts of autobiographical character, at the moments when the memory of one's own childhood is evoked, that "I" implies a dialogue between the "I" and some other "I" (I as the Other) due to the time distance, and in the short stories, "I" is almost always accompanied by some Other, in this case by "my cousin Emilia" (the title of a novel/short stories cycle by Urošević). When creating the persona of Emilia, Urošević, probably unconsciously, opened the door to a street of surrealistic literature and when this little girl went through it, she anticipated the most powerful attributes of the surrealist typology: woman-child, woman-initiator into secrets, but also womandemon. The ambivalent character of Emilia is in the style of the sweet-bitter taste of children's games as a synthesis of the funny and scary. "We screamed with fear and pleasure," we read in his book Childhood, Summer, the City.

In the spirit of the unique magic of childhood and children's unreserved belief in miracles, the mythical creature unicorn and "the marvellously rare, almost uncatchable whistling dog, a creature of the winter that wanders the snow covered spaces, a glistening ghost of the northern parts" were created (Урошевиќ 2011: 145-146). The short stories "Unicorn in the Backyard" and "The Whistling Dog" are set against the background of the dilemma between fiction and faction, rational and irrational - in the style of fantasy; but the lucid play around the true, real existence of the unicorn and the whistling dog carries in it the charm of Borgesian erudite sailing through the centuries and encyclopaedias (just as a reminder, Borges is the author of the Book of Imaginary Beings - Manual de Zoologia Fantástica); it also carries the charm of a shift of the borders of literature: "Where does the real end, and where does the invented begin?" These two short stories are a parable of the conflict and animosity between the world of reality, which a priori excludes the existence of an unicorn and a whistling dog, 
on the one hand, and on the other - the world of fantasy which has to assume the existence of these beings, a conflict in which the cruelty of the world is too strong for the uncommon, imaginary, and somnambulistic. The death of the unicorn and the vanishing of the whistling dog in Urošević's stories is probably a metaphorical announcement of the end of the miraculous childhood time.

\section{Reading the city}

VladaUrošević builds his own "poetics of space" (Gaston Bachelard) on the map of the real Skopje, but Skopje is very rarely mentioned in the titles of his texts. Such rare examples are the autobiographic Skopje Childhood, the short story The Ship Called Skopje, the poems A Night of Full Moon over Skopje or The Mysteries of Skopje. The approach to the city is dual: 1.Phenomenological - Skopje as a product of a specific civilization model. According to Renate Lachmann, "the city appears as a locus, a sum of loci where imagines are deposited - i.e. images of history, of culture, of experience" (Lachmann 2004); and 2. As destiny - a topos which determines and marks the author's biography and is related to his identity as a writer. Still, the literary vision of Skopje is not identical with the geographic map of the city. If the city is a "tumultuous sea" (to borrow a term from Bachelard), and the poet a "lonely surfer on the waves of the city" bathed in the waters of imagination, then the city seems to be melting away, just to be re-shaped by the author at his own will.

Consequently, the city in literature is a simulacrum and has the same status as the imaginary sites: the buildings, the mazes, the parks. "Even as a simulacrum, the city, the specific city, obtains the fictive dimension that gives it the authority of a site of memory" (Lachmann 2004). Memory appears in the role of a founder of a hyperreality, to paraphrase Baudrillard, and generates something real without reality. Therefore, the urban needs to be seen also from the semiotic point of view, as an concord of signs, as reading and decoding of those signs, or, simply, the city is a cryptogram, a coded message or a "chaotic manuscript", as declared by Urošević in the poem The Secrets of the City where we read:

Messages flow through the city: tiny

flickering sparkles, vibrations, hardly

legible signs, a telegraph of chances (...)

... And the entire city

is a chaotic manuscript, unpaginatedpages, lost connections... 
And it is precisely those "lost connections" that are the initial stimulus for Urošević. What excites his imagination is not the intention to make Skopje a centre of some imaginary or semi-imaginary world, and emblem of his writings, of the type of Markes's Macondo, Sabato's Buenos Aires or Joyce's Dublin. "In my case, Skopje imposes itself as a theme", the author explains - there is no system in the making of the mosaic of the city (Јанковски 2003: 61). Still, if Dublin has James Joyce, London - Charles Dickens, and Paris - Charles Baudelaire, we can say that Skopje has Vlada Urošević. In his poems, as well as in his short stories and novels, Skopje is much more designed according to the surrealist typology of the city, with certain deviations, of course, so that we could, highly hypothetically, describe this typology in the following way: the city-dream, the city-labyrinth, the city-mystery, the city-palimpsest, the citymemory...

To me, the image of Skopje (...) - was the image of a paradise lost", the author explains on one occasion, and adds: "I cannot free myself of that image of the bygone Skopje which was at one point lost to me" (the author refers to the period of World War II, when his family was deported) "and then again, as of 1947, returned to me, so that Skopje is the city with which I have sentimental bonds and with the lines of which - with whose life, streets - my own memories are intertwined and all of my path to maturation. That is why Skopje is inevitably part of my experience of the world (Јанковски 2003: 57).

Vlada Urošević, like a modern Dionysius in the City, spontaneously yielding to the "art of walks" (Guillaume Apollinaire), compiles an imaginary album of pictures of the city under the Skopje Fortress, an album in which history and everyday life intertwine, as do reality and fantasy, myth and dream, the past and the dream, the past and the future.... Regardless of whether the theme is Skopje of the time before the big earthquake (the disastrous Skopje earthquake of 1963) or some somnambulistic Skopje (perhaps the "hypnopolis" of the title of one of his books of poems), the image of the city-labyrinth is always estranged, given from a position of strangeness. In this sense, it is interesting to mention, for example, the bond between the city and the sea. Skopje is surrounded by mountains, yet:

...sometimes in winter, from across the mountains in the west, pushing its way through some ravines, there comes to Skopje a warm breath in which one feels the sea, a certain soft humidity in which there is something of the sea air, says Urošević and continues: I find those hint sthatthereis a sea in the distanc every exciting and, ingeneral, these tiny signs of certain closeness with the sea climate in the Macedonian landscape mean a lot to mе. (Јанковски 2003: 113) 
The relation city-sea and its meaning for this author is an overture for probably the most fascinating experience of the city as otherness, in the spirit of that consistently fostered formula given already in his first book of poems Some Other City (1959), which has grown into a leading (auto)poetic principle for the work of Vlada Urošević. In other words, in the well-known city the author manages to see some "other" city which is not to be found on the geographic maps: neither literally nor figuratively. An extraordinary example of a literal discovery of "some other city" is the short story The Night Coach:

(...) The coachman seemed to know some secret map of the city, as if well-versed in its hidden most passages. (...) We were whisked through the city whose plan was changed by the moonlight. The night had become a huge unexplored area that we were cruising, we, the sole witnesses of its duality. (Урошевиќ 2011: 57)

The short story "The Ship Called Skopje" functions along similar lines: "This story is about the ship 'Skopje' which really existed in the Yugoslav navy," Urošević remembers and goes on:

I think it was a cargo ship. At the end of its career, it was broken to pieces, and sold as scrap metal. But before that, its captain did something wonderful - he rescued the ship anchor and had it sent to the city of Skopje as a present, and it still stands on the quay of the Vardar - the river which has never been navigable, at least not in the part passing through Skopje - as a symbol of the interconnection of the different parts of the world by waterways and travels. And that happened several years after the publication of my short story and in a way made it complete (Јанковски 2003: 84).

The story of The Ship Called Skopje ends in a nostalgic tone:

Do you too sometimes hear the ship in the foggy November nights? What does it tell you? Doesn't it lead you to believe that distant things are suddenly near? Doesn't it? Do you too have that feeling that at those moments we sail? And that in the next moment we shall touch the already sensed form of the unknown?

(Урошевиќ 2011: 119)

Metaphorically, the real Skopje becomes an occasion for harmony, for establishment of bonds and analogies with other cities and places, spatially distant and geographically incompatible, but which intersect in the author's memory matrix (following some inner logic of their own) and suddenly become utterly correspondent. What we have here is recognition of the traces of our own in that of the others, that Baudelairian ideal of correspondences fostered by the surrealists as well. Incidentally, this state of the spirit, the déjà $v u$ state, has its 
psychoanalytical justification and interpretation, but in the case of Urošević it results in wonderful and unique images. For instance, in Skopje Childhood he says:

It was a city of people that went out into the night to feel the movement of the air, in that lovers way that I witnessed many years later in the evenings in Cairo (Урошевиќ 2011:14).

Or, on the Greek island of Zakynthos, "I had the feeling I'd arrived before my grandfather's vineyard” (Јанковски 2003:114). Or:

This is theVardar, not the Brahmaputra!

What are Indian temples doing in Skopje!

- as we read in Night of Full Moon over Skopje.

This poem, Night of Full Moon over Skopje, considered to be typically surrealistic, is probably the height of the masterfully derived analogies:

in the city aquarium swim fish from the South Seas

(...) But Skopje

has never had a City Aquarium,

somebody shouted. So what?

And further on:

The Stone Bridge is not made of stone;

...Aldebaran

A star of third degree apparent magnitude,

Stands over theVodno;

...The fire in the Treska Furniture Factory

Was caused by Piccolomini³;

...Daut-Pasha Hamam raises its twelve breasts to the heavens

Like some Artemis of Ephesus,

...Surrealism is not dead!

Says the graffito on a freshly painted wall, etc.

The city has somewhat shifted its position:

if we had a compass

we would see that it now lies under the stars.

Nothing is the same...

(Урошевиќ 2011: 182-191)

3 In 1689, the Austrian General Piccolomini burned down the Macedonian city of Skopje to prevent the spread of cholera. 
- concludes the lyrical subject. And all of this is the doing of the Moon, which, acting as a stageprop, frequently plays the role of a semantic "cut" (according to Lotman) both inVlada Urošević's poetry and in his prose works. "The moon would grant everything in the city the power to grow and grow endlessly," Marco Polo says to Kublai Khan in Italo Calvino's Invisible Cities (Калвино 2005: 88).

A very similar idea pulsates on the pages of Paul Auster's Moon Palace (1989), a novel also based on the mystery of the correlation of separate aspects of the city. For instance, "the wilderness" of Central Park in New York leads to the wilderness in the desert of Utah; the streets of New York's China Town lead to the Pacific Coast and farther, to China; the history of America is as old as the history of the city and leads to new frontiers, to the Pacific and to the Moon. Coincidences multiply, and the city becomes the entrance to the mysteries of life, past and present:

Still, write to me to this address: Skopje

a city in which the Moon

considers it its duty

to mix the cards

of the possible and the impossible

- says Urošević in the finale of his poem "Night of Full Moon over Skopje" (Урошевиќ 2011: 182-191).

\section{Landscapes painted with dream}

In his intimate diaries, Baudelaire notes: "Art should not paint what it sees, but what it dreams". For Breton, the dream is "the source of inspiration". And Urošević consciously chooses the "isle of Hypnos" for his "port of domicile". The poetics of dream is a heraldic sign, a distinguishing mark of his entire work, and his permanent inspiration. The motto "I dream, ergo I am" seems to apply to him perfectly. The coordinates of his Poetic Dream (or "poetic Zen") are not to be found in the geographic maps because the "compass of the dream" leads to the "starry orchards" open only to the initiated - to those who dream. And the supreme "secret of the dreamers" (according to the poem of the same title in the book Starry Scales, 1973) is: "Sleepers sleep, /only the dreamers dream". This is the poetic appeal/password for admission into the secret:

I'm fascinated by dream as one of the ways in which our inner being attempts to create some other reality out of reality. And this fascination has been spurred, undoubtedly, by the fantasy literature, on the one hand, and by surrealism, on the other 
- declares Urošević in his conversations with the young Macedonian writer and essayist Jankovski (Јанковски 2003:110) on the subject of the dream as the essential determinant in his creative Eros. It is not by chance that the poet brings the possibilities of the dream "to expand the borders of reality" and "to conquer the freedom of the spirit" into correlation with his own affinities for the fantastic and surreal as paradigms of the imaginary and the oneiric experience immanent in Urošević's entire body of writings. Because the dream is the end of the familiar reality and the beginning of some other reality, be it fantastic or surreal, which is subject to different laws and logic, but just as true and crucial for our existence. To Urošević, dreamers are "People Who Have a Dream Instead of a Home" (from his book of poems The Dreamer and the Void), not in the sense of homeless people, but as privileged human beings who have the opportunity/ power to conquer the freedom of spirit: to step out of the borders of reason and reality and to leave to some other place, to some new and unknown regions. To live in the dream is to sail on board of a "drunken boat" between the being and non-being, between the worlds which are and those that are not; living in a dream is to have trust in the night, in the irrational, in the unfathomable. The dream is a night rhapsody of our "I".

Dream operates with a film technique/projection of frames: the curtain is raised and as if in a film or on the TV screen the pictures-illuminations follow each other fragmentarily and in accordance with certain illogical rules of their own. What fascinates is the impressiveness, the vital energy and dynamism of the visual in the works of Urošević. As regards the chronotopicality of the images, it is interesting to note that they spread kaleidoscopically in both directions: horizontally (forward-backward) and vertically (upward and downward). Or, we dream/travel extra-temporally, into the past and into the future, into our memories and our hopes and longings, as well as extra-spatially, into the void/ infinity within and without the human being.

Vlada Urošević is fascinated by the mysterious and never completely predictable passes that lead from reality to dream and from the oneiric spaces to the ordinary everyday life, the intertwining and interflowing of dream and reality, their complementarity and concord. Something similar to the knowledge reached by the characters in one of his prose poems in the book with a paradigmatic title Hypnopolis (1986):

The travelogue writers, who entered and passed through this city during the night, usually say that its narrow streets and alleys are full of small, poorly lit bookshops full of rare books, of ancient geographical maps and butterflies from far off lands. (...)

Those who stayed in the city only during the day usually tell about dull, grey streets where the shops have no names and sell nothing special but only items for daily use. 
Those who compared the texts of both kinds of writers have developed a rather peculiar theory: evidently, they say, there are one real city and another one, which exists only in the dreams of its inhabitants. But, which city is real and which unreal, they can't tell.

The suggested hesitation reveals the dream as a mystery and enigma without solution. Just like childhood and the city.

Urošević travels/dreams on the ship named (be) longing for elsewhere: his desire and the need for dislocation, for a journey (real or imaginary) into unfamiliar faraway places (a particular journey) or into a different (abstract) time is a journey between the Real and the Imaginary. As a man of letters, Vlada Urošević is an unquenchable spirit with enormous power to penetrate past the manifest, to take a step beyond the possible and, to quote William Blake, "to open the doors of perception" to some new and unknown worlds; to discover even in the familiar reality of "here" and "now" some magic and some mysterious, unusual beauty. The aristocracy of the poetic/artistic sensibility never dies.

\section{References}

Башлар, Г. (2002). Поейика на йростиорой. Скопје: Табернакул.

Јанковски В. (2003). Ог̄леgало за заг̄айкайа: разг̄овори со Влаgа Урошевиќ. Скопје: Сигмапрес.

Калвино, И. (2005). Невияливите грраgови. Скопје: Или-или.

Лахман, Р. (2004). Мнемотехника и симулакрум. Мираж / Mirage, e-comparative journal. Пристапено на 23.04.2013:

http://mirage.com.mk/index.php/mk/spisanie-mirage/2599/intertekstualnost/276 -2013-04-23-12-22-08

Урошевиќ, В. (1986). Хийнойолис. Скопје: Македонска книга. Урошевиќ, В. (2011). Дейсииво, летио, грpag. Скопје: Темплум.

Улих, К. (2003). Историчност и модерност. Во Катица Кулавкова (уред.). Теорија на

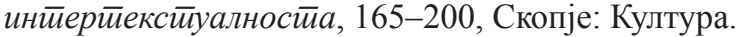

